Nat. Hazards Earth Syst. Sci., 19, 441-454, 2019

https://doi.org/10.5194/nhess-19-441-2019

(C) Author(s) 2019. This work is distributed under the Creative Commons Attribution 4.0 License.

\title{
Simulating the effects of weather and climate on large wildfires in France
}

\author{
Renaud Barbero, Thomas Curt, Anne Ganteaume, Eric Maillé, Marielle Jappiot, and Adeline Bellet \\ Irstea, Mediterranean ecosystems and risks, Aix-en-Provence, France
}

Correspondence: Renaud Barbero (renaud.barbero@irstea.fr)

Received: 3 October 2018 - Discussion started: 24 October 2018

Accepted: 15 February 2019 - Published: 1 March 2019

\begin{abstract}
Large wildfires across parts of France can cause devastating damage which puts lives, infrastructure, and the natural ecosystem at risk. In the climate change context, it is essential to better understand how these large wildfires relate to weather and climate and how they might change in a warmer world. Such projections rely on the development of a robust modeling framework linking large wildfires to present-day atmospheric variability. Drawing from a MODIS product and a gridded meteorological dataset, we derived a suite of biophysical and fire danger indices and developed generalized linear models simulating the probability of large wildfires ( $>100 \mathrm{ha}$ ) at $8 \mathrm{~km}$ spatial and daily temporal resolutions across the entire country over the last two decades. The models were able to reproduce large-wildfire activity across a range of spatial and temporal scales. Different sensitivities to weather and climate were detected across different environmental regions. Long-term drought was found to be a significant predictor of large wildfires in flammabilitylimited systems such as the Alpine and southwestern regions. In the Mediterranean, large wildfires were found to be associated with both short-term fire weather conditions and longerterm soil moisture deficits, collectively facilitating the occurrence of large wildfires. Simulated probabilities on days with large wildfires were on average 2-3 times higher than normal with respect to the mean seasonal cycle, highlighting the key role of atmospheric variability in wildfire spread. The model has wide applications, including improving our understanding of the drivers of large wildfires over the historical period and providing a basis on which to estimate future changes to large wildfires from climate scenarios.
\end{abstract}

\section{Introduction}

Large wildfires in France have received much attention recently due to the threat they pose to ecosystems, society, property, and the economy. In the Mediterranean region, large wildfires threaten many of the ecosystems components and their recurrence can induce a loss of resilience (Pausas et al., 2008), potential shifts in plant composition and structure (Vennetier and Ripert, 2009; Frejaville et al., 2013) or soil losses. Additionally, the growth of the wildland-urban interface (WUI) has increased wildfire risk, the cost of suppression, and our vulnerability across the region (LampinMaillet et al., 2011; Modugno et al., 2016; Ruffault and Mouillot, 2017; Fox et al., 2018), and will continue to do so given future demographic trends. Although wildfire extent does not systematically reflect wildfire intensity and the related impacts (Tedim et al., 2018), large wildfires are usually the most destructive for both ecosystems and infrastructure.

Wildfire ignitions in Europe were strongly related to a range of human activities (Ganteaume et al., 2013), with arson and negligence being the main causes in the French Mediterranean (Ganteaume and Jappiot, 2013; Curt et al., 2016; Ganteaume and Guerra, 2018). Despite the accidental and unintentional nature of most wildfire ignitions, wildfire spread in the French Mediterranean is generally enabled and driven by a range of weather-to-climate processes operating at different timescales such as long-term drought (Hernandez et al., 2015b; Turco et al., 2017) and favorable large-scale weather conditions including synoptic blocking (Hernandez et al., 2015a) or the Atlantic ridge weather type (Ruffault et al., 2017). These large-scale weather patterns are known to facilitate wildfire spread through different mechanisms: wind speed (for the Atlantic ridge) and anomalously warm conditions (for the synoptic blocking) (Ruffault et al., 2016). 
While wind-induced wildfires may arise due to strong winds that accelerate the rate of spread in a specific direction, heatinduced wildfires (also called plume-driven wildfires) arise due to anomalously warm conditions that increase fuel dryness and flammability and facilitate wildfire spread in all directions (Lahaye et al., 2017), contingent on topography and fuel structure. Collectively, heatwave, wind speed, and drought conditions during previous months have been shown to enhance the potential for large wildfires (Hernandez et al., 2015a, b; Ruffault et al., 2018). However, most of these previous efforts have exploited regional datasets of burned areas across parts of southeastern France commencing in early 1970s, and little attention has been devoted to understanding processes in other regions except in the Alps (Dupire et al., 2017).

Over the long-term, a substantial reduction in wildfire activity was observed in the 1990s across the French Mediterranean due to suppression and prevention strategies (Ruffault and Mouillot, 2015; Curt and Frejaville, 2017), decoupling wildfire trends from climate expectations (Fréjaville and Curt, 2017). However, the 2003 heatwave induced wildfire-prone meteorological conditions across the region, impeding suppression efforts and putting 2003 as one of the most extreme years in terms of burned area over the last six decades (Ganteaume and Barbero, 2018). The continued intensification and increased frequency of heatwaves in the future due to climate change (Vautard et al., 2013; Guerreiro et al., 2018), alongside the gradual precipitation deficit simulated by climate models across southern Europe during the fire season (Abatzoglou et al., 2018; Cramer et al., 2018), raises legitimate concerns about the sustainability of current fire policies and strategies. Additionally, the accumulation of fuel loads due to past wildfire suppression efforts within a long-term forest recovery context across the Mediterranean (Abadie et al., 2017) is widely thought to have created favorable ground conditions for wildfire spread and the occurrence of large wildfires (Curt and Frejaville, 2017).

In this context, it is essential to develop a modeling framework resolving the complex relationships linking weather-toclimate variability to the occurrence of large wildfires. Such a model is still lacking due to observational inhomogeneities in wildfire detection across the country, hampering the compilation of a homogeneous database. Drawing from a global remote-sensing database of burned area, we sought here to develop a nationwide statistical model including wildfireprone regions overlooked in previous studies. The model is expected to advance our understanding of processes and drivers of large wildfires and to provide guidance on how weather and climate variability may increase the occurrence of large wildfires in France under a warmer climate.

\section{Data and methods}

\subsection{Wildfire data}

We used the Moderate Resolution Imaging Spectroradiometer (MODIS) Firecci v5.0 product developed within the framework of the European Space Agency's Climate Change Initiative (CCI) program and available in the period 20012016 (Chuvieco et al., 2016). This product is based on MODIS on board of the Terra polar heliosynchronous orbiting satellite. The burned-area algorithm combined temporal changes in near-infrared MERIS-corrected reflectances based on MOD09GQ of the MODIS sensor at $250 \mathrm{~m}$ spatial resolution with active fire detection from the standard MODIS thermal anomalies product, following a two-phase algorithm (Alonso-Canas and Chuvieco, 2015). Complementary to the surface reflectance product, the daily MOD09GA Collection 6 product was also used to extract information on the quality of the data. Although small wildfires are generally difficult to detect with satellite observations due to the timing of the scan or cloud-cover impairment of remote sensing, our focus on large wildfires is expected to minimize this uncertainty.

We excluded MODIS fires located within agricultural lands using CORINE Land Cover 2012 data (https://land. copernicus.eu/pan-european/corine-land-cover, last access: 28 Febuary 2019) as well as prescribed fires related to pastoral practices during the cool season (November-March), since these fires are generally under control and do not put infrastructure or ecosystems at risk. Spatially and temporally adjacent MODIS pixels were aggregated using the location and the date of the first detection to form consistent wildfire events. Pixels belonging to the same wildfire event were required to be within a maximum distance of 4 pixels (to minimize inaccuracies in burned-area detection within a pixel) and to have adjacent burning dates. The 22785 MODIS pixels extracted from 2001 to 2016 across France were found to form 894 distinct wildfire events. We then defined large wildfires as exceeding 100 ha ( $N=156$ large wildfires) following Ganteaume and Barbero (2018), a threshold corresponding here to the 83 th percentile of the distribution of wildfire area. The average large-wildfire area was found to be 398 ha, with the largest wildfire reaching 7675 ha. Finally, we regridded this information onto an $8 \mathrm{~km}$ resolution grid to facilitate the comparison with meteorological data (see Sect. 2.2).

\subsection{Weather and climate data}

Meteorological variables were obtained from the qualitycontrolled SAFRAN (Système d'Analyse Fournissant des Renseignements Atmosphériques a la Neige; Analysis system providing data for the snow model) reanalyses, providing minimum and maximum temperature, relative humidity, precipitation, and wind speed over France from 2001 to 
Table 1. Candidate variables in the modeling framework.

\begin{tabular}{ll}
\hline Name & Acronym \\
\hline 1. Fine fuel moisture code & FFMC \\
2. Duff moisture code & DMC \\
3. Drought code & DC \\
4. Initial-spread index & ISI \\
5. Build-up index & BUI \\
6. Fire-weather index & FWI \\
7. Forest McArthur Fire Danger Index & FFDI \\
8. F-Index & FINDEX \\
9. Nesterov Fire Danger Index & NFDI \\
10. Fosberg Fire Weather Index & FFWI \\
11. Effective drought index & EDI \\
12. Potential evapotranspiration & PET \\
13. Standardized precipitation index & SPI \\
14. Soil wetness index & SWI \\
\hline
\end{tabular}

2016 (Vidal et al., 2010a, b; Vidal et al., 2012) on a daily basis and over an $8 \mathrm{~km}$ grid.

Drawing from the SAFRAN data, we derived a suite of fire-weather and drought indices (see Table 1) intended to reflect different timescales of variability that are widely thought to facilitate wildfire spread from synoptic (weather) to interannual (climate) scales (Barbero et al., 2015a; Nogueira et al., 2017). Fire-weather variables included the Canadian Forest Fire Weather Index system (fine fuel moisture code (FFMC), build-up index (BUI), duff moisture code (DMC), initial spread index (ISI), drought code (DC), and fire-weather index (FWI)) (Van Wagner, 1987). Although these indices were empirically calibrated for estimating whether atmospheric conditions and fuel moisture content are prone to wildfire development in a jack pine forest of Canada (Van Wagner, 1987), the FWI system has proven useful in Mediterranean regions (Dimitrakopoulos et al., 2011; Fox et al., 2018; Lahaye et al., 2017) as well as in Alpine environments (Dupire et al., 2017). We also included in our analysis other fire-weather indices that have been shown to be useful for estimating fire danger conditions across parts of the world including the Forest McArthur Fire Danger Index (Dowdy et al., 2010), the F-Index (Sharples et al., 2009), the Nesterov Fire Danger Index (Nesterov, 1949) and the Fosberg Fire Weather Index (Fosberg, 1978). Further information on each of these fire-weather variables and how they relate to wildfire activity can be found in the literature.

Additionally, we used a series of fast- and slow-reacting drought indices to detect flash and chronic droughts that are often associated with large wildfires. These indices include potential evapotranspiration (PET) based on the PenmanMonteith equation, the effective drought index (EDI) (Byun and Wilhite, 1999), here integrating precipitation over the last 30 days to detect a short-term precipitation deficit, and the standardized precipitation index (SPI) based on a non- parametric framework (Farahmand and AghaKouchak, 2015) and computed on 6-month windows to detect a long-term precipitation deficit. The SPI has already shown some skill in predicting burned area across different parts of the globe (Turco et al., 2018). Finally, we used the more sophisticated soil wetness index (SWI) developed by CNRM (Centre National de la Recherche Météorologique). This last index was derived from ISBA (Noilhan and Mahfouf, 1996), a soilbiosphere-atmosphere interaction model based on soil characteristics across France, reflecting the moisture available for the plants. The SWI integrates the propagation of moisture from the superficial surface layer to the root zone (Barbu et al., 2011).

\subsection{Environmental stratification}

The relationship between weather-to-climate and wildfire activity in France is mediated through vegetation and the complex topography of the region (Fig. 1a) alongside human factors (Fréjaville and Curt, 2015; Ganteaume and LongFournel, 2015; Ganteaume and Guerra, 2018). Given the compounding influence of these environmental factors, we developed separate models using an environmental stratification (Fig. 1b) based on climate data, topography, and geographical position (Metzger et al., 2005; Jongman et al., 2006), assuming that the weather-to-climate forcing on large wildfires is relatively consistent within each of these regions. Only a brief description of these environmental units is given here. The northern region (Atlantic central in Metzger et al., 2005), the less fire-prone region (Table 2), corresponds to a temperate climate in which average summer temperatures are relatively low. The Alpine region spans highmountain conditions typical of the alpine ranges of southern Europe, which are dominated by conifer forests at high elevation and broadleaf forest at low elevation. The western region (Lusitanean in Metzger et al., 2005), corresponds to the southern Atlantic climate characterized by warm and dry summers coupled with mild and humid winters. Further south, the Mediterranean area is stratified into three distinct environmental regions: the Mediterranean mountains (labeled "Mnts" in the figures), which combine the influence of both Mediterranean and mountain climates (including various species such as Fagus sylvatica, Pinus sp., Quercus pubescens), the Mediterranean north, which contain holm-oak- and cork-oak-dominated vegetation (Quercus ilex, Quercus suber, Pinus sp.) and the Mediterranean south, a low-elevation area (Fig. 1a) spanning the Rhône delta. The spatial extent of each region allows for the pooling of a decent number of MODIS wildfires needed to develop robust models. We however acknowledge the existence of subregional variations in human factors (e.g., ignition and suppression) and that other biogeographic units with homogeneous attributes with respect to wildfire regime and climatic conditions may yield different results (Fréjaville and Curt, 2015). 

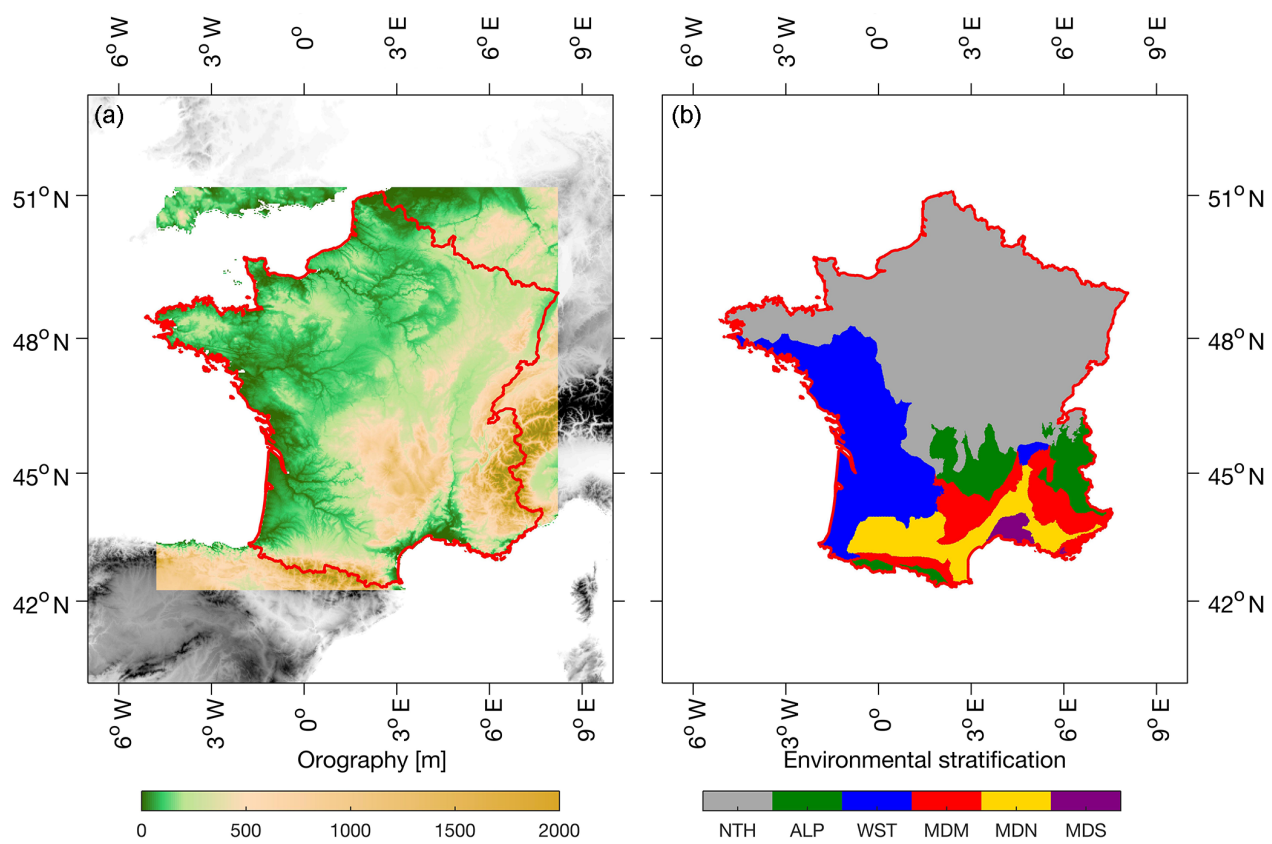

Figure 1. (a) Orography in France. The red contour shows the outlines of the investigated French region. (b) Environmental stratification based on climate data, data on the ocean influence and geographical position (Metzger et al., 2005; Jongman et al., 2006). Abbreviations are NTH - north (Atlantic central in Metzger et al., 2005), ALP - Alpine, WST - west (Lusitanean in Metzger et al., 2005), MDM Mediterranean mountains, MDN - Mediterranean north, and MDS - Mediterranean south

Table 2. This table provides, for each environmental region, the number of wildfires, the number of large wildfires ( $>100$ ha), the contribution of large wildfires to regional burned area and the contribution of large wildfires to national burned area.

\begin{tabular}{lrrrr}
\hline Environment region & No. wildfires & No. large wildfires & Contribution to regional BA & Contribution to national BA \\
\hline North & 49 & 6 & $61.8 \%$ & $1.9 \%$ \\
Alpine & 41 & 8 & $69.1 \%$ & $2.3 \%$ \\
West & 101 & 19 & $63.6 \%$ & $5.4 \%$ \\
Mediterranean mountains & 289 & 51 & $83.9 \%$ & $34.8 \%$ \\
Mediterranean north & 309 & 59 & $75.9 \%$ & $25.7 \%$ \\
Mediterranean south & 105 & 13 & $72.4 \%$ & $7.1 \%$ \\
\hline
\end{tabular}

\subsection{The modeling framework}

\subsubsection{Generalized linear models}

Empirical models linking weather and climate to wildfires have received much attention in the climate change context (Riley and Thompson, 2017) and multiple model specifications have been introduced in the literature to simulate wildfire activity (Boulanger et al., 2018). We sought here to develop separate models for each environmental region to simulate the probability of a large wildfire (given an ignition) at $8 \mathrm{~km}$ spatial and daily resolutions, based purely on the weather-to-climate forcing. Simulating the day-to-day variability has the advantage of detecting short-duration synoptic conditions, otherwise masked in monthly or seasonal timescales.
We used generalized linear models (GLMs) with a stepwise regression using all predictors listed in Table 1. GLMs have already been used to simulate the occurrences of large wildfires in other regions of the world (Stavros et al., 2014a, b; Barbero et al., 2014, 2015b) given their ability to model the relationship between a dichotomous variable (presence or absence of large wildfires) and a set of predictor variables. For each day of the MODIS period (2001-2016) and each cell of the $8 \mathrm{~km}$ grid, the binomial predictand $(y)$ was coded as 1 if a large wildfire was observed, and 0 otherwise. This binary response is modeled as the probability $(P)$ of observing a large wildfire via a logistic model with a logit link such as

$$
P(y=1 \mid x)=\frac{\exp \left(\beta^{\prime} x\right)}{1+\exp \left(\beta^{\prime} x\right)}
$$


where $\beta^{\prime}=\left(\beta_{0}, \beta_{1}, \ldots \beta_{p}\right)$ is a vector of coefficients relating the probability of wildfires to $p$ covariates via the relationship $\beta^{\prime} x=\beta_{0}+\beta_{1} x_{1}+\ldots+\beta_{p} x_{p} . P$ is intrinsically bounded in the interval $[0,1]$. We considered each observation of the predictor variables as independent samples despite the inherent spatial autocorrelation and serial correlation. This violates the assumption of independence between samples and overestimates the number of degrees of freedom. However, these effects are mitigated with the use of a random sampling design in model development (see below), although it is not intended to completely remove the true spatial autocorrelation. Predictor variables that did not significantly improve the model were discarded from stepwise model selection procedure using the Bayesian information criterion (BIC) since the penalty for additional parameters is higher in BIC than in Akaike information criterion (AIC), consequently favoring more parsimonious models (Murtaugh, 2009). Also, we did not allow interactive and nonlinear terms in logistic equations.

\subsubsection{Model selection uncertainty}

While a model may be developed using all $8 \mathrm{~km}$ grid cells available through the period and the region, numerous caveats arise that limit the model robustness, particularly given the huge imbalance between 0 (absence) and 1 (presence). Selecting the "best" approximating model from one single sample would raise the following question: would the same model be selected with another sample? The model selection uncertainty is of primary importance (Burnham and Anderson, 2002), especially when competing models exist to describe the unknown state of the complex climate-wildfire relationship (Podschwit et al., 2018). The use of replications in logistic regressions allows avoiding instability in the results due to sampling bias and helps reduce structural uncertainty. We used resampling methods combining the strength of probabilistic and statistical methods (Guns and Vanacker, 2012) to assess model stability and to achieve a proper tradeoff between bias and variance (Burnham and Anderson, 2002). To do this, we conducted a case control experiment (Keating and Cherry, 2004) and generated 1000 bootstrap samples to estimate model selection frequencies $\left(\pi_{i}\right)$. Each sample includes all large-wildfire occurrences (1) as well as 50000 randomly chosen nonoccurrences $(0)$. Each of the resampled data corresponds to a specific grid cell on a specific day. The maximum likelihood theory provides estimates of the parameters $\beta^{\prime}$ and the BIC-best model is found for each bootstrap sample. Finally, the model selection relative frequencies $\left(\pi_{i}\right)$ are computed as the sums of the frequencies where model $i$ was selected as the best, divided by the total number of bootstraps. We used the model with the highest $\pi_{i}$ from these bootstraps in subsequent modeling as we considered this model to represent the most stable relationships in a given region. Note that the simulated probabilities were derived using all data available so that the sum of simulated probabilities in a given region reflects the total number of large wildfires observed.

Receiver-operating characteristic (ROC) plots was used to evaluate the model performance, as ROC statistics provide information for a range of possible threshold values to classify a grid cell on a specific day as "prone to large wildfire" and rapidly gives an overall idea of model skill. The ROC curve shows the false-positive rate vs. the true-positive rate and the area under the ROC curve ranges from 0.5 (random prediction) to 1.0 (perfect prediction). Also, we examined simulated probabilities expressed as anomalies with respect to the mean annual cycle both 80 days prior to and 80 days following observed large-wildfire days at the $8 \mathrm{~km}$ grid cell level. This allows us to determine whether simulated probabilities on large-wildfire days were locally higher than what we would expect from the seasonal forcing alone and how fast these large-wildfire-prone conditions develop.

\section{Results and discussion}

\subsection{Large-wildfire contribution to total burned area}

In each region, the annual frequency of large wildfires strongly shaped interannual variations in annual burned area (Fig. 2), with an overall contribution in total burned area from 2001 to 2016, ranging from $62 \%$ (north) to $84 \%$ (Mediterranean mountains) (Table 2). Large wildfires in the Mediterranean north and Mediterranean mountains were the strongest contributors to national total burned area (Table 2). Note that the Mediterranean mountain region has experienced a dramatic increase in large wildfires and annual burned area in response to the 2003 heatwave. It is thus readily apparent that a few large wildfires are responsible for the majority of the burned area and that a better understanding of drivers and processes of these specific events is of utmost importance.

\subsection{Model selection and regional variability}

Most models showed high skill (Fig. 3). The area under the curve (AUC) was the highest for the Mediterranean north, which is also the region with the largest sample of large wildfires, while the Mediterranean south model had the lowest predictive power. In this region, a true-positive rate hardly exceeding 0.8 was associated with a false-negative rate exceeding 0.7 , indicating that large wildfires in that region are less related to the weather-to-climate forcing.

Table 3 shows the best model selected in each environmental region alongside the relative model selection frequencies $\left(\pi_{i}\right)$ from applying BIC to each of the 1000 bootstrap samples. In five out of the six regions, models were selected as the best in $>90 \%$ of the simulations. However, the Mediterranean mountains model had much lower selection frequencies $(36 \%)$. Note that a lower frequency of selection does not mean that the model has a lower skill, but rather 

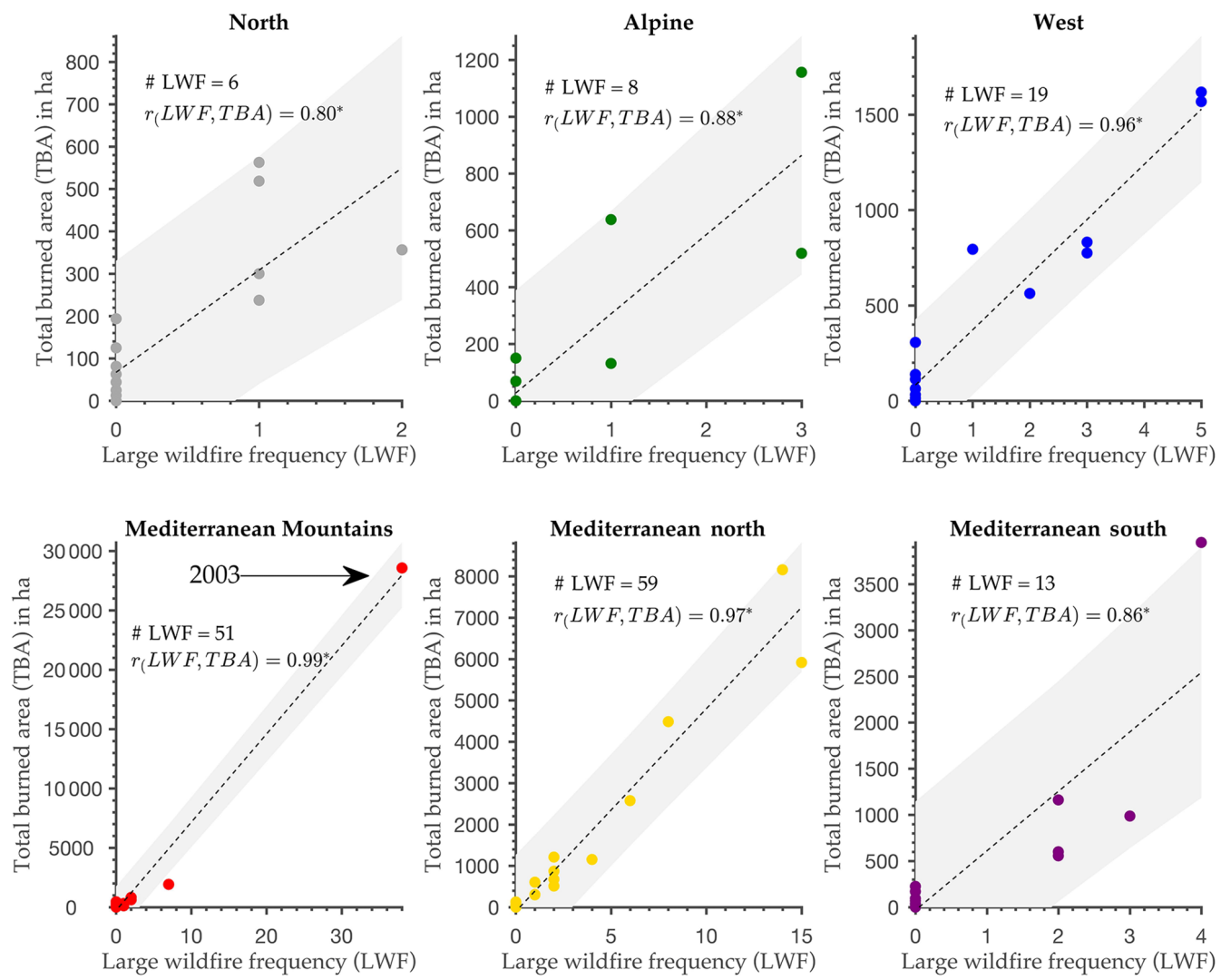

Figure 2. Interannual relationships between the annual frequency of large wildfires ( $>100 \mathrm{ha}$ ) and the total annual burned area. The total number of large wildfires as well as Pearson correlations are indicated for each region. The symbol * indicates significant correlations at the $95 \%$ confidence level. The linear fitting and the $95 \%$ confidence intervals are also shown.

Table 3. Equations describing daily large-wildfire ( $>100 \mathrm{ha}$ ) probabilities at $8 \mathrm{~km}$ for each environmental region. The second column indicates the number of large wildfires observed from 2001 to 2016 . The third column gives the $\beta^{\prime} x$ parameters and the last column indicates the model selection frequencies, i.e., the percent of bootstraps for which there was agreement.

\begin{tabular}{lrlr}
\hline Environment region & No. large wildfires & $\frac{\exp \left(\beta^{\prime} x\right)}{1+\exp \left(\beta^{\prime} x\right)}$ & Bootstrap $\pi_{i}$ \\
\hline North & 6 & $\beta^{\prime} x=-20.674+$ FFMC $\times 0.0767$ & 100 \\
Alpine & 8 & $\beta^{\prime} x=-14.828+$ SPI $\times(-1.9868)$ & 98 \\
West & 19 & $\beta^{\prime} x=-16.242+\mathrm{DC} \times 0.0054$ & 100 \\
Mediterranean mountains & 51 & $\beta^{\prime} x=-9.3825+\mathrm{DMC} \times 0.0165+\mathrm{SWI} \times(-7.4097)$ & 36 \\
Mediterranean north & 59 & $\beta^{\prime} x=-8.7438+\mathrm{FWI} \times 0.067+\mathrm{SWI} \times(-13.036)$ & 92 \\
Mediterranean south & 13 & $\beta^{\prime} x=-11.932+\mathrm{DMC} \times 0.0183$ & 100 \\
\hline
\end{tabular}

that other combinations of predictors are possible. The table also shows the different predictor variables selected in the stepwise procedure and indicates how the weather-toclimate forcing can affect large wildfires very differently depending on what kinds of environmental conditions predominate, as already shown in previous works across the USA (Stavros et al., 2014a; Barbero et al., 2014; Podschwit et al., 2018). Table A1 in Appendix A provides the typical range of each explanatory variable on days with large wildfires. In the north, the best model uses only FFMC, an index reflecting the flammability of litter and fine fuels. As opposed to Mediter- ranean regions, where FFMC quickly saturates in early summer due to overall low soil moisture conditions, this index seems to be useful for tracking large-wildfire potential in more humid climates where fine fuels dominate. By contrast, the best models for Alpine and western regions are based on slow-reacting indices (SPI for the Alpine region and DC for the western region), both reflecting chronic soil moisture deficit and low fuel moisture levels (Dupire et al., 2017). This suggests that large wildfires in these more humid and more flammability-limited systems are mainly enabled by slowevolving drought. The picture is slightly more complex in 


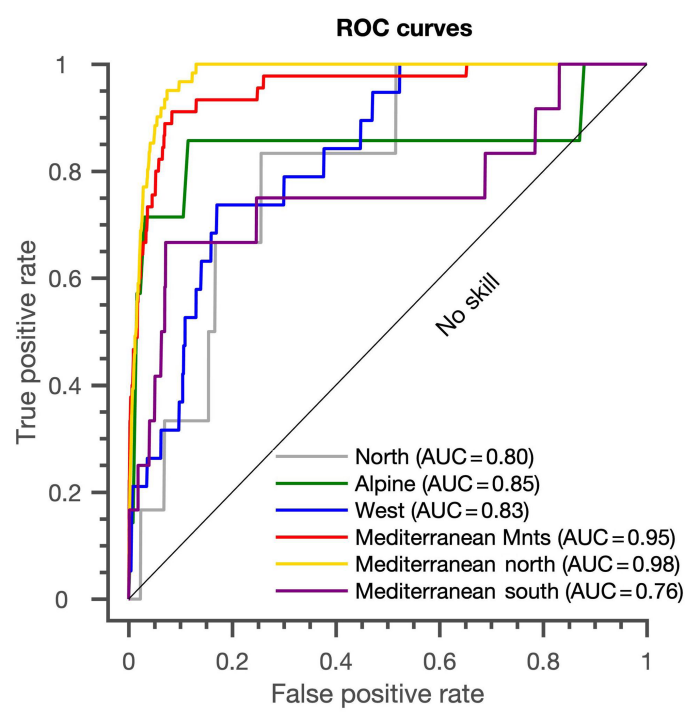

Figure 3. Area under the curve (AUC) illustrating the performance of each model. Mnts stands for mountains.

both the Mediterranean mountains and Mediterranean north. For instance, the best model in the Mediterranean north combines the information provided by the FWI (fire-weather metric) with the SWI (soil moisture content metric). In fact, a strong decrease in the SWI in summer, corresponding to a reduction in plant-available soil moisture level, accelerates the desiccation and may lead to vegetation mortality (Barbu et al., 2011), which in turn facilitates wildfire spread. Besides, an increase in the FWI, which also integrates the expected rate of spread in response to wind speed, once again underlines the strong role of wind speed in wildfire spread in the Mediterranean north. In other words, large wildfires occur when multiple conditions are gathered, namely high winds, dry fuel and low soil moisture levels. This illustrates how complementary fire-weather and soil moisture indices are, and how they may, collectively, improve the ability to track the potential for large wildfires.

It is noteworthy that the effect of wind speed on large wildfires is only revealed through the FWI in the Mediterranean north. The absence of wind speed as a significant factor in other regions may arise due to the temperature decrease associated with wind spells in the French Mediterranean (Ruffault et al., 2017), with contrasting effects on commonly used fire-weather indices that were designed to increase with temperature. This may also indicate the stronger role of fuel moisture in these regions in response to slower climatic variations, regardless of what short-term fire weather does.

\subsection{Seasonal and interannual variability in observed and simulated large wildfires}

The mean seasonal cycle, featuring a peak in August in most regions, is well reproduced in the simulations (Fig. 4 and Table 4). However, some large wildfires were also seen in the
Table 4. Spearman rank correlations between large wildfires (> 100 ha) observed and that expected from simulated probabilities at the monthly (second column) and interannual (third column) timescales. The symbol * indicates significant correlation at the $95 \%$ confidence level.

\begin{tabular}{lll}
\hline Environment region & $\begin{array}{l}\text { Monthly } \\
\text { variations }\end{array}$ & $\begin{array}{l}\text { Interannual } \\
\text { variations }\end{array}$ \\
\hline North & 0.56 & 0.45 \\
Alpine & $0.58^{*}$ & 0.23 \\
West & $0.73^{*}$ & $0.58^{*}$ \\
Mediterranean mountains & $0.68^{*}$ & 0.45 \\
Mediterranean north & $0.73^{*}$ & $0.65^{*}$ \\
Mediterranean south & $0.67^{*}$ & 0.22 \\
\hline
\end{tabular}

spring and in September in the north and Alpine regions respectively, a feature that is not reproduced in the model either due to sample size limitations or other human factors not included in the models. Figure 5 shows the spatiotemporal patterns of mean daily simulated probabilities from May to October. The potential for large wildfires emerges in the Mediterranean south first and then propagates northwards into the Mediterranean mountains and along the west coast before slowly decaying in October. An animation of daily simulated probabilities from 2001 to 2016 is available in the Supplement (VideoS1.mov).

Models were also able to simulate, to some extent, interannual variations in large wildfires (Fig. 6 and Table 4), including the exceptional 2003 outbreak in the Mediterranean mountains. As expected, interannual variance in simulated probabilities was much lower than that of large wildfires observed (Fig. 6) due to the continuous nature of probabilities (in contrast to the strongly intermittent nature of large wildfire), thereby underestimating (overestimating) the probability of very likely (unlikely) events and resulting in a variance deflation.

\subsection{Local simulated probabilities}

Figure 7 shows simulated probabilities expressed as anomalies with respect to the mean local seasonal cycle during a period spanning 80 days before to 80 days after large wildfires pooled over the entire country. It is readily apparent that simulated probabilities progressively increased until the days with large wildfire, reaching values 2-3 times higher than normal and then slowly decaying towards normal conditions. This temporal pattern was, however, variable across environmental regions (Fig. 8) depending on the predictor variables selected (Table 2). In fact, the slowly increasing probabilities evident in the Alpine region and the Mediterranean mountains mimic the slow variations of the SPI and the SWI, respectively, and align with global change-type drought (Breshears et al., 2005; Ruffault et al., 2018). By contrast, fasterincreasing probabilities in the Mediterranean north on days 

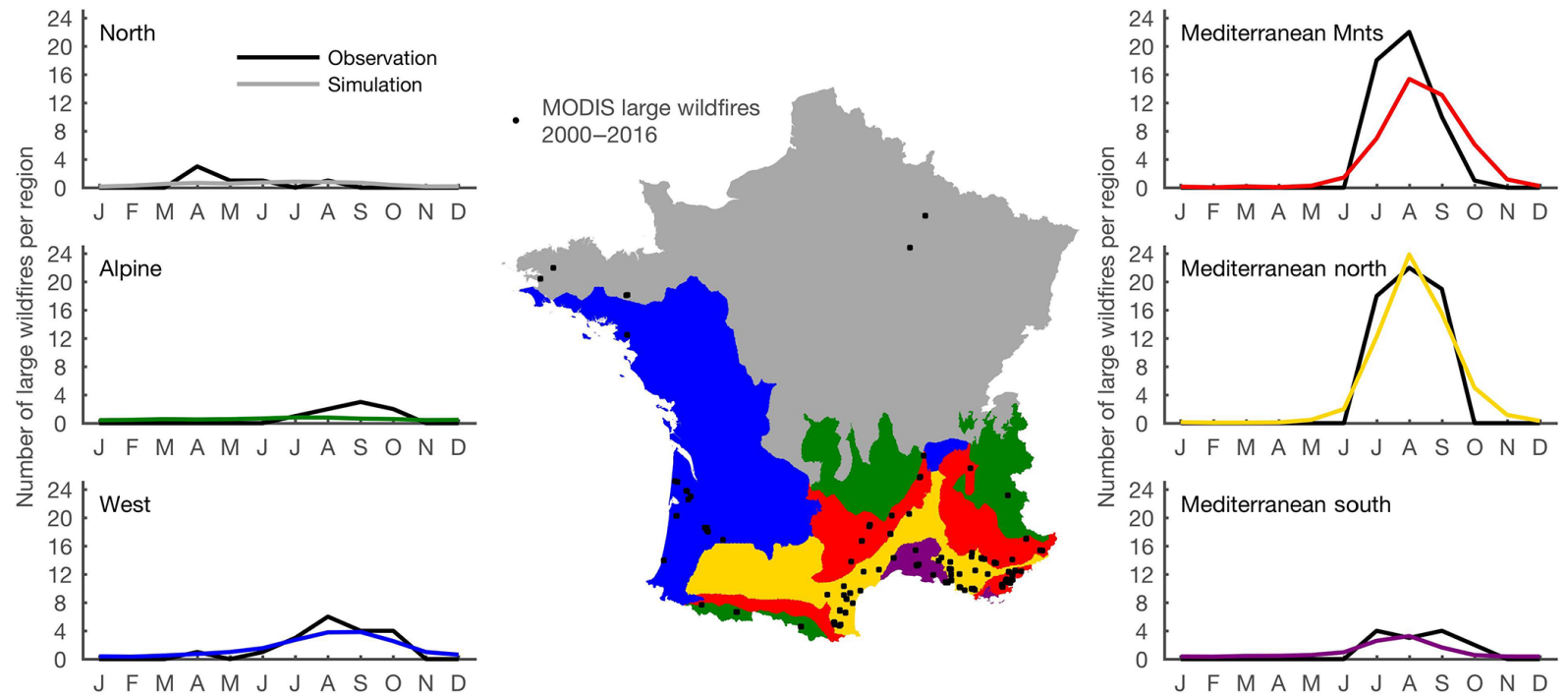

Figure 4. Observed (black) and simulated (color) total number of large wildfires ( $>100$ ha) per month in each environmental region. The middle panel shows the location of large wildfires during the April-October season from 2001 to 2016. Mnts is mountains.
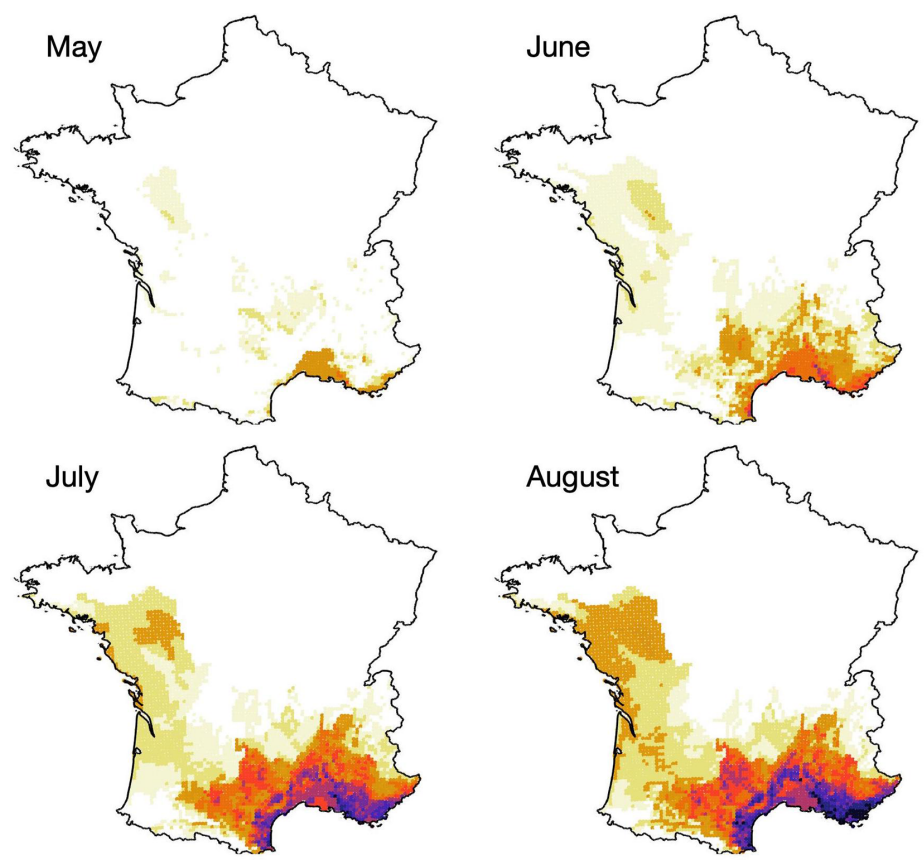

0.0005826

0.0003427

0.0002016

0.0001186

0.0000698

0.0000410

0.0000241

0.0000142

0.0000084

0.0000049
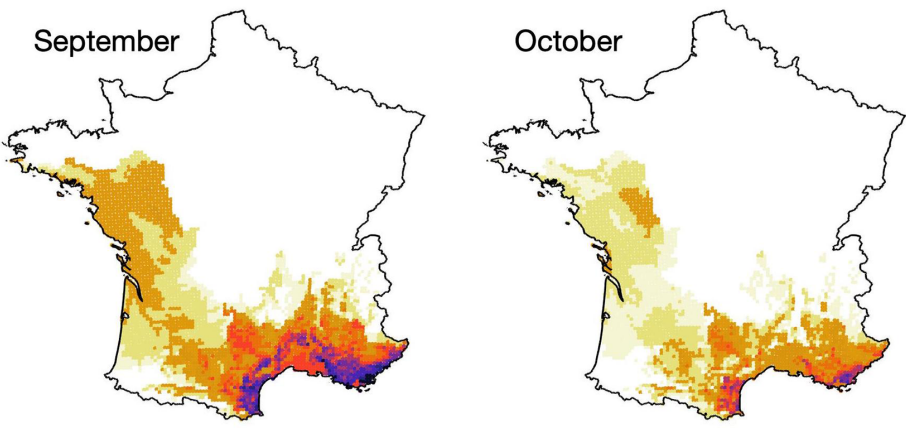

0.0000029

0.0000017

0.0000010

0.0000000

Figure 5. Daily large-wildfire ( $>100$ ha) probabilities across months averaged from 2001 to 2016. Note the highly nonlinear color bar (probabilities in the highest class are $>582$ times higher than those in the first class). 
(a) Observation

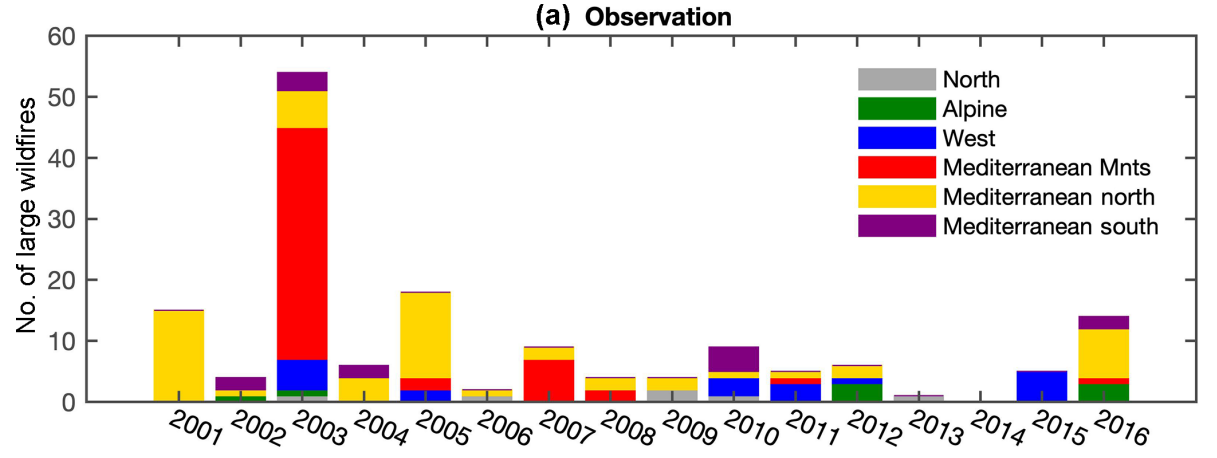

(b) Simulation

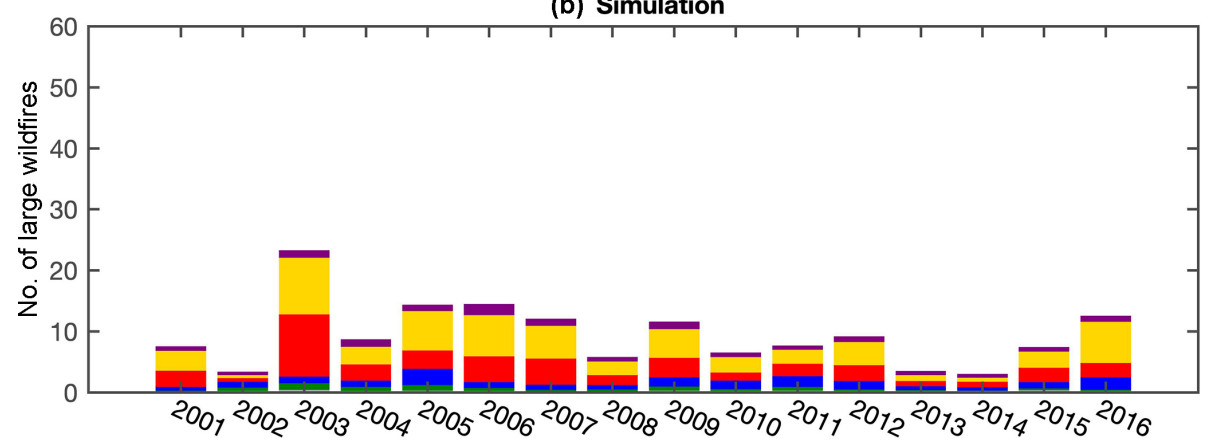

Figure 6. Observed (a) and simulated (b) total number of large wildfires ( $>100$ ha) per year in each environmental region. Mnts is mountains.

with large wildfires reflect the role of short-term fire-weather conditions, again highlighting different generating mechanisms across the regions.

\subsection{Potential applications and limitations}

This modeling framework has multiple potential applications. First, it could be implemented in a real-time fashion using meteorological forecasts. This may complement traditional forecasts based on FWI only. Indeed, the FWI only measures the potential intensity of wildfire and this quantity is not always straightforward in the real world. In this regard, our model translates a series of fire-weather and drought indices into a probability of the occurrence of large wildfires that could be useful in decision-making. Second, our model may serve as a basis on which to simulate future changes to large wildfires based on future climate projections from the EURO-Cordex project. Such projections will help better understand future changes and will provide the information decision makers need for successful adaptation to climate change.

However, several caveats and well-known limitations apply to our modeling framework. First, our model is based purely on weather and climate and ignores human activities (ignition or suppression). Indeed, drought is one component of a complicated wildfire system (Littell, 2018) and our modeling framework is obviously contingent on ignition and fuels. Although human activities add a less understood

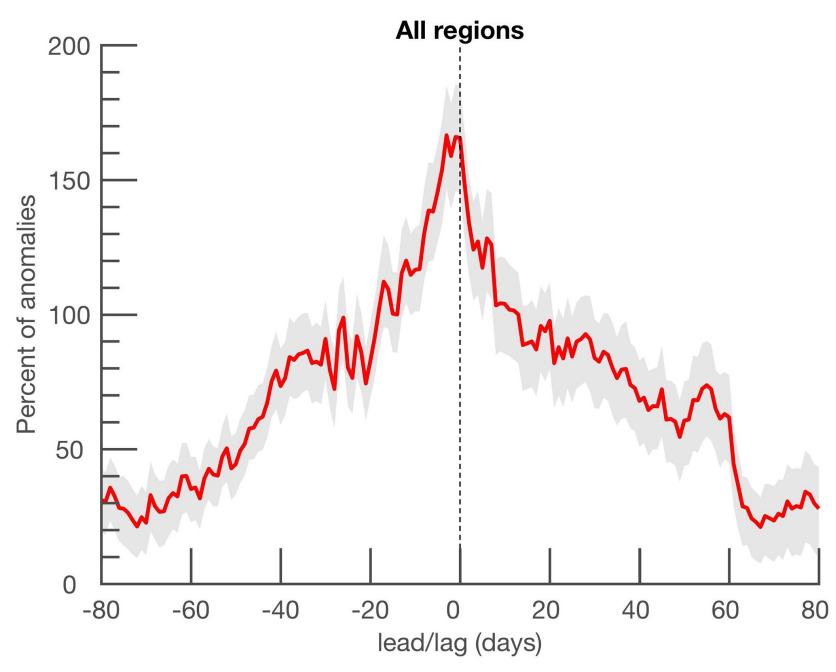

Figure 7. Composites of local simulated probabilities (expressed as percent with respect to the mean seasonal cycle, i.e., $100 \%$ indicates that probabilities are two times higher than normal) relative to the large-wildfire ( $>100 \mathrm{ha}$ ) days. The $95 \%$ confidence intervals of the composite means are computed using 1000 bootstrapped datasets. The envelope of confidence indicates the 2.5 and 97.5 percentiles of the composite means obtained from the bootstrapped datasets. 


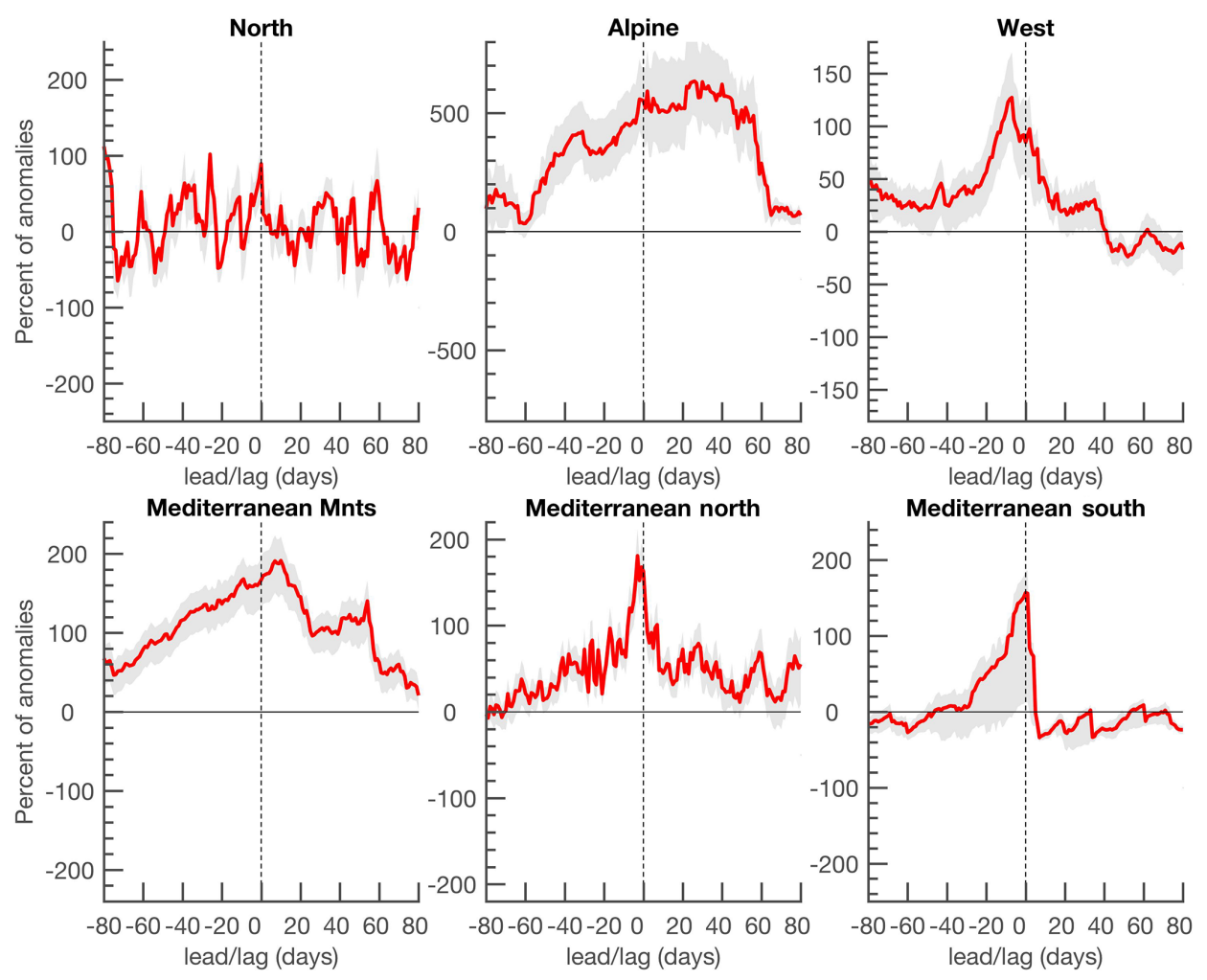

Figure 8. Same as Fig. 7 but for specific regions. Note the different ranges on the $y$ axis. Mnts is mountains.

and therefore less predictable component (Littell, 2018), including human factors (Costafreda-Aumedes et al., 2017). as well as causes of wildfire ignition (Ganteaume and Guerra, 2018) may improve model skill. All these factors should be considered in the more complex context of risk assessment. Second, the environmental stratification used here (Metzger et al., 2005) has proven useful to aggregate large wildfires and develop different models (and should be considered in future pan-European climate-wildfire modeling efforts) but we acknowledge that this stratification is likely, as is any other stratification, to mix up large wildfires with different human causes and different climate drivers. Third, information on fuel connectivity could also improve model skill and help target the regions at risk. A recent study has shown that wildfire spread in the French Mediterranean is severely limited by fuel connectivity in some regions (Ganteaume and Barbero, 2018). Finally, developing a statistical model with a very limited number of large wildfires is a major limitation in some regions. This limitation is obviously inherent to the modeling of extreme events and was partly overcome with the use of a resampling approach. Nonetheless, a longer record of wildfires would certainly allow for the stabilization of the equations.

\section{Conclusions}

This study provides a statistical modeling framework of large wildfires from the weather-to-climate forcing. The model simulates the daily probability of large wildfires onto an $8 \mathrm{~km}$ grid across the country. The best explanatory variables differ from one region to another, indicating that the atmospherelarge-wildfire coupling is strongly mediated by environmental conditions. Long-term drought was found to be a significant predictor of large wildfires in flammability-limited systems such as the Alpine and southwestern regions. In the Mediterranean, large wildfires were found to be associated with both short-term fire-weather conditions and longer-term soil moisture deficits, collectively facilitating the occurrence of large wildfires. In this regard, the SWI based on soil characteristics and reflecting the soil moisture available for the plant appears to be a useful metric for tracking large wildfires and may complement traditional fire-weather indices. This modeling framework once again highlights the strong control that atmospheric variability exerts over the occurrence of large wildfires across a range of timescales.

Data availability. The Safran database was provided by MétéoFrance and is available upon request. The Fire_cci v5.0 product can be accessed at https://geogra.uah.es/fire_cci/ (last access: 28 February 2019; Chuvieco et al., 2016). 


\section{Appendix A}

Table A1. Typical range of explanatory variables on a day with large wildfires. The range indicates the 2.5 and 97.5 percentiles $(95 \%$ confidence interval) of the composite means obtained from 1000 bootstrapped datasets.

\begin{tabular}{lll}
\hline Environment region & Predictor $1(95 \% \mathrm{CI})$ & Predictor 2 $(95 \% \mathrm{CI})$ \\
\hline North & FFMC $(76.7 ; 82.5)$ & \\
Alpine & SPI $(-2.0 ;-1.1)$ & \\
West & DC $(661.6 ; 767.4)$ & \\
Mediterranean mountains & DMC $(86.1 ; 108.9)$ & SWI $(0.14 ; 0.18)$ \\
Mediterranean north & FWI $(26.9 ; 30.9)$ & SWI $(0.12 ; 0.14)$ \\
Mediterranean south & DMC $(77.2 ; 131.2)$ & \\
\hline
\end{tabular}


Supplement. The supplement related to this article is available online at: https://doi.org/10.5194/nhess-19-441-2019-supplement.

Author contributions. RB carried out the analysis and wrote the paper. TC, AG, EM, MJ, and AB contributed to the design of the methodology. All authors discussed the results and contributed to writing the paper.

Competing interests. The authors declare that they have no conflict of interest.

Special issue statement. This article is part of the special issue "Spatial and temporal patterns of wildfires: models, theory, and reality". It is a result of the conference EGU 2017, Vienna, Austria, 23-28 April 2017.

Acknowledgements. The authors appreciate the constructive reviews by Dennis Fox and an anonymous reviewer who helped improve the quality of this manuscript.

Edited by: Mário Pereira

Reviewed by: Dennis Fox and one anonymous referee

\section{References}

Abadie, J., Dupouey, J.-L., Avon, C., Rochel, X., Tatoni, T., and Bergès, L.: Forest recovery since 1860 in a Mediterranean region: drivers and implications for land use and land cover spatial distribution, Landscape Ecol., 33, 289-305, https://doi.org/10.1007/s10980-017-0601-0, 2017.

Abatzoglou, J. T., Williams, A. P., and Barbero, R.: Global emergence of anthropogenic climate change in fire weather indices, Geophys. Res. Lett., 46, 326-336, https://doi.org/10.1029/2018GL080959, 2018.

Alonso-Canas, I. and Chuvieco, E.: Global burned area mapping from ENVISAT-MERIS and MODIS active fire data, Remote Sens. Environ., https://doi.org/10.1016/j.rse.2015.03.011, 2015.

Barbero, R., Abatzoglou, J., Steel, E., and Larkin, N.: Modeling very large-fire occurrences over the continental United States from weather and climate forcing, Environ. Res. Lett., 9, 124009, https://doi.org/10.1088/1748-9326/9/12/124009, 2014.

Barbero, R., Abatzoglou, J., Kolden, C., Hegewisch, K., Larkin, N., and Podschwit, H.: Multi-scalar influence of weather and climate on very large-fires in the Eastern United States, Int. J. Climatol., 35, 2180-2186, https://doi.org/10.1002/joc.4090, 2015a.

Barbero, R., Abatzoglou, J., Larkin, N., Kolden, C., and Stocks, B.: Climate change presents increased potential for very large fires in the contiguous United States, Int. J. Wildland Fire, 24, 892-899, https://doi.org/10.1071/WF15083, 2015b.

Barbu, A. L., Calvet, J.-C., Mahfouf, J.-F., Albergel, C., and Lafont, S.: Assimilation of Soil Wetness Index and Leaf Area Index into the ISBA-A-gs land surface model: grassland case study, Bio- geosciences, 8, 1971-1986, https://doi.org/10.5194/bg-8-19712011, 2011.

Boulanger, Y., Parisien, M.-A., and Wang, X.: Model-specification uncertainty in future area burned by wildfires in Canada, Int. J. Wildland Fire, 27, 164-175, https://doi.org/10.1071/WF17123, 2018.

Breshears, D. D., Cobb, N. S., Rich, P. M., Price, K. P., Allen, C. D., Balice, R. G., Romme, W. H., Kastens, J. H., Floyd, M. L., Belnap, J., Anderson, J. J., Myers, O. B., and Meyer, C. W.: Regional vegetation die-off in response to global-changetype drought, P. Natl. Acad. Sci. USA, 102, 15144-15148, https://doi.org/10.1073/pnas.0505734102, 2005.

Burnham, K. P. and Anderson, D. R.: Model Selection and Multimodel Inference: a Practical Information-Theoretic Approach, 2nd Edn., Springer-Verlag, New York, 2002.

Byun, H. R. and Wilhite, D. A.: Objective quantification of drought severity and duration, J. Climate, $12, \quad 2747-2756$, https://doi.org/10.1175/15200442(1999)012<2747:OQODSA>2.0.CO;2, 1999.

Chuvieco, E., Yue, C., Heil, A., Mouillot, F., Alonso-Canas, I., Padilla, M., Pereira, J. M., Oom, D., and Tansey, K.: A new global burned area product for climate assessment of fire impacts, Global Ecol. Biogeogr., 25, 619-629, https://doi.org/10.1111/geb.12440, 2016 (data available at: https: //geogra.uah.es/fire_cci/, last access: 28 February 2019).

Costafreda-Aumedes, S., Comas, C., and Vega-Garcia, C.: Humancaused fire occurrence modelling in perspective: A review, Int. J. Wildland Fire, 26, 983-998, https://doi.org/10.1071/WF17026, 2017.

Cramer, W., Guiot, J., Fader, M., Garrabou, J., Gattuso, J.-P., Iglesias, A., Lange, M. A., Lionello, P., Llasat, M. C., Paz, S., Peñuelas, J., Snoussi, M., Toreti, A., Tsimplis, M. N., and Xoplaki, E.: Climate change and interconnected risks to sustainable development in the Mediterranean, Nature Climate Change, 8, 972-980, https://doi.org/10.1038/s41558-018-0299-2, 2018.

Curt, T. and Frejaville, T.: Wildfire Policy in Mediterranean France: How Far is it Efficient and Sustainable?, Risk Analysis, 38, 472488, https://doi.org/10.1111/risa.12855, 2017.

Curt, T., Fréjaville, T., and Lahaye, S.: Modelling the spatial patterns of ignition causes and fire regime features in southern France: Implications for fire prevention policy, Int. J. Wildland Fire, 25, 785-796, https://doi.org/10.1071/WF15205, 2016.

Dimitrakopoulos, A. P., Bemmerzouk, A. M., and Mitsopoulos, I. D.: Evaluation of the Canadian fire weather index system in an eastern Mediterranean environment, Meteorol. Appl., 18, 8393, https://doi.org/10.1002/met.214, 2011.

Dowdy, A. J., Mills, G. A., Finkele, K., and de Groot, W.: Index sensitivity analysis applied to the Canadian Forest Fire Weather Index and the McArthur Forest Fire Danger Index, Meteorol. Appl., 17, 298-312, https://doi.org/10.1002/met.170, 2010.

Dupire, S., Curt, T., and Bigot, S.: Spatio-temporal trends in fire weather in the French Alps, Sci. Total Environ., 595, 801-817, https://doi.org/10.1016/j.scitotenv.2017.04.027, 2017.

Farahmand, A. and AghaKouchak, A.: A generalized framework for deriving nonparametric standardized drought indicators, Adv. Water Resour., 76, 140-145, https://doi.org/10.1016/j.advwatres.2014.11.012, 2015.

Fox, D., Carrega, P., Ren, Y., Caillouet, P., Bouillon, C., and Robert, S.: How wildfire risk is related to urban planning and Fire 
Weather Index in SE France (1990-2013), Sci. Total Environ., 621, 120-129, https://doi.org/10.1016/j.scitotenv.2017.11.174, 2018.

Fréjaville, T. and Curt, T.: Spatiotemporal patterns of changes in fire regime and climate: defining the pyroclimates of south-eastern France (Mediterranean Basin), Climatic Change, 129, 239-251, https://doi.org/10.1007/s10584-015-1332-3, 2015.

Fréjaville, T. and Curt, T.: Seasonal changes in the human alteration of fire regimes beyond the climate forcing, Environ. Res. Lett., 12, 035006, https://doi.org/10.1088/1748-9326/aa5d23, 2017.

Frejaville, T., Curt, T., and Carcaillet, C.: Bark flammability as a fire-response trait for subalpine trees, Front. Plant Sci., 4, 466, https://doi.org/10.3389/fpls.2013.00466, 2013.

Ganteaume, A. and Barbero, R.: Contrasting large fire regimes in the French Mediterranean, Nat. Hazards Earth Syst. Sci. Discuss., https://doi.org/10.5194/nhess-2018-263, in review, 2018.

Ganteaume, A. and Guerra, F.: Explaining the spatioseasonal variation of fires by their causes: The case of southeastern France, Appl. Geogr., 90, 69-81, https://doi.org/10.1016/j.apgeog.2017.11.012, 2018.

Ganteaume, A. and Jappiot, M.: What causes large fires in Southern France, Forest Ecol. Manage., 294, 76-85, https://doi.org/10.1016/j.foreco.2012.06.055, 2013.

Ganteaume, A. and Long-Fournel, M.: Driving factors of fire density can spatially vary at the local scale in south-eastern France, Int. J. Wildland Fire, 24, 650-664, https://doi.org/10.1071/WF13209, 2015.

Ganteaume, A., Camia, A., Jappiot, M., San-Miguel-Ayanz, J., Long-Fournel, M., and Lampin, C.: A review of the main driving factors of forest fire ignition over Europe, Environ. Manage., 51, 651-662, https://doi.org/10.1007/s00267-012-9961-z, 2013.

Guerreiro, S. B., Dawson, R. J., Kilsby, C., Lewis, E., and Ford, A.: Future heat-waves, droughts and floods in 571 European cities, Environ. Res. Lett., 13, 034009, https://doi.org/10.1088/17489326/aaaad3, 2018.

Guns, M. and Vanacker, V.: Logistic regression applied to natural hazards: rare event logistic regression with replications, Nat. Hazards Earth Syst. Sci., 12, 1937-1947, https://doi.org/10.5194/nhess-12-1937-2012, 2012.

Hernandez, C., Drobinski, P., and Turquety, S.: How much does weather control fire size and intensity in the Mediterranean region?, Ann. Geophys., 33, 931-939, https://doi.org/10.5194/angeo-33-931-2015, 2015a.

Hernandez, C., Keribin, C., Drobinski, P., and Turquety, S.: Statistical modelling of wildfire size and intensity: a step toward meteorological forecasting of summer extreme fire risk, Ann. Geophys., 33, 1495-1506, https://doi.org/10.5194/angeo-33-14952015, 2015b.

Jongman, R. H., Bunce, R. G., Metzger, M. J., Mücher, C. A., Howard, D. C., and Mateus, V. L.: Objectives and applications of a statistical environmental stratification of Europe, Landscape Ecol., 21, 409-419, https://doi.org/10.1007/s10980-005-6428-0, 2006.

Keating, K. A. and Cherry, S.: Use and Interpretation of Logistic Regression in Habitat-Selection Studies, J. Wildlife Manage., 68, 774-789, 2004.

Lahaye, S. A., Curt, T. D., and Fre, T.: What are the drivers of dangerous fires in Mediterranean France ?, Int. J. Wildland Fire, 27, 155-163, https://doi.org/10.1071/WF17087, 2017.
Lampin-Maillet, C., Long-Fournel, M., Ganteaume, A., Jappiot, M., and Ferrier, J. P.: Land cover analysis in wildlandurban interfaces according to wildfire risk: A case study in the South of France, Forest Ecol. Manag., 261, 2200-2213, https://doi.org/10.1016/j.foreco.2010.11.022, 2011.

Littell, J. S.: Drought and Fire in the Western USA: Is Climate Attribution Enough?, Current Climate Change Reports, 111, https://doi.org/10.1007/s40641-018-0109-y, Springer International Publishing, 2018.

Metzger, M. J., Bunce, R. G., Jongman, R. H., Mücher, C. A., and Watkins, J. W.: A climatic stratification of the environment of Europe, Global Ecol. Biogeogr., 14, 549-563, https://doi.org/10.1111/j.1466-822X.2005.00190.x, 2005.

Modugno, S., Balzter, H., Cole, B., and Borrelli, P.: Mapping regional patterns of large forest fires in WildlandeUrban Interface areas in Europe, J. Environ. Manage., 172, 112-116, https://doi.org/10.1016/j.jenvman.2016.02.013, 2016.

Murtaugh, P. A.: Performance of several variable-selection methods applied to real ecological data, Ecol. Lett., 12, 1061-1068, https://doi.org/10.1111/j.1461-0248.2009.01361.x, 2009.

Nogueira, J., Rambal, S., Barbosa, J., and Mouillot, F.: Spatial Pattern of the Seasonal Drought/Burned Area Relationship across Brazilian Biomes: Sensitivity to Drought Metrics and Global Remote-Sensing Fire Products, Climate, 5, 42, https://doi.org/10.3390/cli5020042, 2017.

Noilhan, J. and Mahfouf, J. F.: The ISBA land surface parameterisation scheme, Global Planet. Change, 13, 145-159, https://doi.org/10.1016/0921-8181(95)00043-7, 1996.

Pausas, J. G., Llovet, J., Rodrigo, A., and Vallejo, R.: Are wildfires a disaster in the Mediterranean basin? A review, Int. J. Wildand Fire, 17, 713-723, https://doi.org/10.1071/WF07151, 2008.

Podschwit, H. R., Larkin, N. K., Steel, E. A., Cullen, A., and Alvarado, E.: Multi-Model Forecasts of Very-Large Fire Occurences during the End of the 21st Century, Climate, 6, 100, https://doi.org/10.3390/cli6040100, 2018.

Riley, K. and Thompson, M.: An Uncertainty Analysis of Wildfire Modeling, in: Natural Hazard Uncertainty Assessment: Modeling and Decision Support, Washington, D.C., American Geophysical Union, https://doi.org/10.1002/9781119028116.ch13, John Wiley \& Sons, Hoboken, New Jersey, 2017.

Ruffault, J. and Mouillot, F.: How a new fire-suppression policy can abruptly reshape the fire-weather relationship, Ecosphere, 6, 119, https://doi.org/10.1890/ES15-00182.1, 2015.

Ruffault, J. and Mouillot, F.: Contribution of human and biophysical factors to the spatial distribution of forest fire ignitions and large wildfires in a French Mediterranean region, Int. J. Wildland Fire, 26, 498-508, https://doi.org/10.1071/WF16181, 2017.

Ruffault, J., Moron, V., Trigo, R. M., and Curt, T.: Objective identification of multiple large fire climatologies: an application to a Mediterranean ecosystem, Environ. Res. Lett., 11, 075006, https://doi.org/10.1088/1748-9326/11/7/075006, 2016.

Ruffault, J., Moron, V., Trigo, R. M., and Curt, T.: Daily synoptic conditions associated with large fire occurrence in Mediterranean France: evidence for a wind-driven fire regime, Int. J. Climatol., 37, 524-533, https://doi.org/10.1002/joc.4680, 2017.

Ruffault, J., Curt, T., Martin-StPaul, N. K., Moron, V., and Trigo, R. M.: Extreme wildfire events are linked to global-changetype droughts in the northern Mediterranean, Nat. Hazards Earth 
Syst. Sci., 18, 847-856, https://doi.org/10.5194/nhess-18-8472018, 2018.

Sharples, J. J., McRae, R. H., Weber, R. O., and Gill, A. M.: A simple index for assessing fire danger rating, Environ. Modell. Softw., 24, 764-774, https://doi.org/10.1016/j.envsoft.2008.11.004, 2009.

Stavros, E. N., Abatzoglou, J., Larkin, N. K., Mckenzie, D., and Steel, E. A.: Climate and very large wildland fires in the contiguous western USA, Int. J. Wildland Fire, 23, 899-914, https://doi.org/10.1071/WF13169, 2014a.

Stavros, E. N., Abatzoglou, J. T., McKenzie, D., and Larkin, N. K.: Regional projections of the likelihood of very large wildland fires under a changing climate in the contiguous Western United States, Climatic Change, 126, 455-468, https://doi.org/10.1007/s10584-014-1229-6, 2014b.

Tedim, F., Leone, V., Amraoui, M., Bouillon, C., Coughlan, M. R., Delogu, G. M., Fernandes, P. M., Ferreira, C., McCaffrey, S., McGee, T. K., Parente, J., Paton, D., Pereira, M. G., Ribeiro, L. M., Viegas, D. X., and Xanthopoulos, G.: Defining Extreme Wildfire Events: Difficulties, Challenges, and Impacts, Fire, 1, 9, https://doi.org/10.3390/fire1010009, 2018.

Turco, M., von Hardenberg, J., AghaKouchak, A., Llasat, M. C., Provenzale, A., and Trigo, R. M.: On the key role of droughts in the dynamics of summer fires in Mediterranean Europe, Sci. Rep.-UK, 7, 81, https://doi.org/10.1038/s41598-017-001169, 2017.

Turco, M., Jerez, S., Doblas-Reyes, F. J., AghaKouchak, A., Llasat, M. C., and Provenzale, A.: Skilful forecasting of global fire activity using seasonal climate predictions, Nat. Commun., 9, 2718, https://doi.org/10.1038/s41467-018-05250-0, 2018.

Van Wagner, C. E.: Development and structure of the Canadian forest fire weather index system, available at: http: //scholar.google.com/scholar?hl=en\&btnG=Search\&q=intitle: Development+and+Structure+of+the+Canadian+Forest+Fire+ Weather+Index+System\#0 (last access: 28 February 2019), 1987.
Vautard, R., Gobiet, A., Jacob, D., Belda, M., Colette, A., Déqué, M., Fernández, J., García-Díez, M., Goergen, K., Güttler, I., Halenka, T., Karacostas, T., Katragkou, E., Keuler, K., Kotlarski, S., Mayer, S., van Meijgaard, E., Nikulin, G., Patarčić, M., Scinocca, J., Sobolowski, S., Suklitsch, M., Teichmann, C., Warrach-Sagi, K., Wulfmeyer, V., and Yiou, P.: The simulation of European heat waves from an ensemble of regional climate models within the EURO-CORDEX project, Clim. Dynam., 41, 2555-2575, https://doi.org/10.1007/s00382-013-1714-z, 2013.

Vennetier, M. and Ripert, C.: Forest flora turnover with climate change in the Mediterranean region: A case study in Southeastern France, Forest Ecol. Manag., https://doi.org/10.1016/j.foreco.2009.09.015, 2009.

Vidal, J.-P., Martin, E., Franchistéguy, L., Habets, F., Soubeyroux, J.-M., Blanchard, M., and Baillon, M.: Multilevel and multiscale drought reanalysis over France with the Safran-Isba-Modcou hydrometeorological suite, Hydrol. Earth Syst. Sci., 14, 459-478, https://doi.org/10.5194/hess-14-459-2010, 2010a.

Vidal, J. P., Martin, E., Franchistéguy, L., Baillon, M., and Soubeyroux, J. M.: A 50-year high-resolution atmospheric reanalysis over France with the Safran system, Int. J. Climatol., 30, 16271644, https://doi.org/10.1002/joc.2003, 2010b.

Vidal, J.-P., Martin, E., Kitova, N., Najac, J., and Soubeyroux, J.M.: Evolution of spatio-temporal drought characteristics: validation, projections and effect of adaptation scenarios, Hydrol. Earth Syst. Sci., 16, 2935-2955, https://doi.org/10.5194/hess-16-29352012, 2012. 